\title{
Fallout of fertilizers set too low, studies warn
}

Jim Giles, London

The internationally agreed technique used to estimate levels of a potent greenhouse gas may be greatly underestimating emissions, researchers have told Nature.

Emissions of nitrous oxide resulting from fertilizer use in Britain may be up to $50 \%$ higher than estimated by current guidelines, according to recent studies. The guidelines may also be hampering attempts to limit emissions, as they fail to reward countries for switching to fertilizers that release less nitrous oxide.

Uncertainties surrounding nitrous oxide levels are greater than for any other greenhouse gas covered by the Kyoto Protocol on climate change. In terms of total emissions, the gas has the greatest global-warming potential after carbon dioxide, roughly on a par with methane. But calculating releases from agricultural soils — the single biggest nitrous oxide source - is difficult because of the many factors that affect how microbes break down nitrogen-containing fertilizers.

Most governments instead stick to guidelines produced in 1996 by the Intergovernmental Panel on Climate Change (IPCC), which estimate that $1.25 \%$ of nitrogen applied as fertilizer is emitted as nitrous oxide. Use of a single rough estimate is judged to be the only solution that will work internationally, given that local variables such as soil type and humidity level significantly affect nitrous oxide production.

But the IPCC encourages governments to use more sophisticated techniques if appropriate peer-reviewed literature becomes available. And there are now many such data.

IMAGE

UNAVAILABLE

FOR COPYRIGHT

REASONS
Researchers in Britain in particular have conducted some of the most detailed studies on nitrogen use, and these put Britain's total nitrous oxide emissions at up to twice the IPCC estimate. The researchers and their colleagues in Germany — where studies suggest that emissions from some agricultural areas may also be twice as high as IPCC estimates - have now told their governments that the IPCC methodology underestimates emissions and needs to be updated.

In one of the most recent studies, to be published later this year, Keith Smith, an environmental scientist at the University of Edinburgh, used a combination of empirical data and modelling to find that annual nitrous oxide emissions from fertilizer use in Scotland have reached 17,000 tonnes, more than half as much again as the $1.25 \%$ estimate.These results tally with nationwide models developed in the past five years by Ute Skiba, a soil microbiologist at the Centre for Ecology and Hydrology in Penicuik, UK.

The British and German environment ministries are now considering updating the methodologies they use, and Germany may even implement new guidelines next year. The situation is not the same in all countries, however. Studies in France and Hungary, for example, suggest that $1.25 \%$ is a good estimate.

UK officials add that because the IPCC system is based on total fertilizer use, it deters countries from investigating a switch to varieties of nitrogen fertilizers that produce less nitrous oxide. In the meantime, they add, the ministry is working with farmers to promote more efficient use of fertilizer.

Additional reporting by Tamara Grüner.

Farm produce: emissions of nitrous oxide from fertilizers may be $\mathbf{5 0} \%$ higher than current estimates.

\section{Gene tests served up to tell fine foods from fakes}

\section{Rachael Williams, Tokyo}

Japan is set to crack down on imitations of its local delicacies - from seaweed to crab - by using genetic testing to check the origins of foodstuffs.

Many Japanese products use their place of origin as a sign of quality, in the same way that real champagne must come from the region in France of the same name. But imitations often end up on the market.

Government officials in Hokkaido, Japan's largest food-supplying region, say that tofu, soba noodles, beans and other products are sometimes sold under a fake Hokkaido label. But in April, the local government will start to protect the region's economic interests by implementing spot checks of products in supermarkets across the country.
The idea of genetic testing of food is not new. The Kyoto-based company Takara Shuzo, for example, has developed a genetic test that can distinguish famous Koshihikari rice - from the Niigata region — from cheaper varieties. It sells kits to retailers so they can check the authenticity of their products.

A similar test has been developed by researchers at the National Institute of Vegetable and Tea Science in Mie Prefecture to allow them to distinguish genuine Tochiotome strawberries from Korean fruit that illicitly bears the Tochiotome label.

And Japan's customs agents last year started using genetic tests on imports of tatami mats - a traditional Japanese floor covering. This should ensure that mats described as Hinomidori are made from the high-quality reeds developed by researchers at the Kumamoto Prefecture Agricultural Research Center.

The challenge in store for Hokkaido will be to identify genetic markers unique to all the products they wish to test. Finding markers for Hokkaido's crab, for example, will be quite a challenge, says Hideyuki Imai, who studies crab genetics at the University of the Ryukyus in Okinawa. If crabs from different regions interbreed with each other, says Imai, it may prove to be impossible.

All this rigorous genetic testing may force up the price of these items, notes Yoshito Tsuya, an agricultural economist at Utsunomiya University, just north of Tokyo. But he thinks that customers will be prepared to pay more to make sure they get the real thing. 